Lung cancer accounts for $12 \%$ of all cancers and has the highest annual rate of mortality in men and women. The overall aim is cure or prolongation of life without evidence of disease. Almost $60 \%$ of patients at the moment of diagnosis are not eligible for radical treatment. Therefore soothing and supportive treatment is the only treatment of choice. Patients with lung cancer who have symptoms of dyspnea, chronic cough, severe pain, exhaustion and cachexia syndrome, fear and depression and significantly reduced physical and intellectual activities are qualified for inpatient or home palliative care. Knowledge about various methods used in palliative treatment allows one to alleviate symptoms that occur in an advanced stage of disease with an expected short survival period. Methods of oncological treatment that are often used in patients with advanced lung cancer include radiotherapy and chemotherapy. Drawing attention to the earlier implementation of palliative care is an objective of research carried out during recent years. Advances in surgical and conservative treatment of these patients have contributed to better outcomes and longer survival time.

Key words: lung cancer, palliative care, quality of life.

\section{Palliative care in patients with lung}

\section{cancer}

\author{
Paulina Farbicka ${ }^{1}$, Andrzej Nowicki ${ }^{2}$
}

${ }^{1}$ Clinical Emergency Ward, 10th Clinical Military Hospital with Outpatient Clinics, Bydgoszcz

2Department of Oncological Nursing, Ludwik Rydygier Collegium Medicum in Bydgoszcz, Nicolaus Copernicus University, Torun

\section{Lung cancer}

Neoplastic disease is one of the main causes of death. Currently in the world cancers are diagnosed in 11 million people each year; for this reason, mortality is about 7 million. The incidence of cancer increases with age, as in the case of the incidence of chronic neurological disorders and cardiovascular disease $[1,2]$. It is estimated that by 2030 the number of new cases of cancer will increase to 26 million, while the number of deaths will reach 17 million per year. The global increase in frequency of cancer is associated with aging of society and risk factors such as smoking and lack of physical activity. Lung cancer has been the most common neoplasm caused by smoking since 1985 [3]. More than half of new cases occur in people over 65 years [4].

Lung cancer accounts for $12 \%$ of all cancers and has the highest annual mortality rate both in men and women. About $29 \%$ of deaths are caused by lung cancer in the United States [5]. Lung cancer is diagnosed at an advanced stage in about $50 \%$ of cases. The general objective is to cure or prolong life without evidence of disease. Gender is to be regarded as an important prognostic factor. Women have a higher survival rate compared to males [6].

Lung cancer is divided into two categories according to its biological characteristics and different ways of treatment. Non-small cell lung cancer (NSCLC) represents 80-85\% of cases, while small cell lung cancer (SCLC) represents $15-20 \%$ only. Risk factors for lung cancer include smoking, passive smoking, exposure to asbestos (mesothelioma), ionizing radiation and certain metals. Lung cancer does not give a good prognosis. This is most commonly due to too late diagnosis, advanced age, coexisting diseases, and hence limited therapy. The most common symptoms include ailments of the respiratory system, such as cough, hemoptysis, shortness of breath and pain in the chest associated with local growth. Symptoms of lung cancer adversely affect the mental and spiritual spheres of patients, lowering their quality of life (QL). Spread of cancer cells to other organs often occurs in patients with lung cancer, mostly to lymph nodes, bones, adrenal glands and brain. Weight loss, lack of appetite, weakness and fatigue are observed in a significant number of patients [7]. Surgical treatment remains the only way for treatment of patients with NSCLC which gives a chance of recovery. Informed patient consent and her/his will to cooperate are required for starting proposed treatment. Before the surgery the patient should be prepared appropriately, must stop smoking, undergo physical rehabilitation and pharmacotherapy. Non-small cell lung cancer is treated surgically at an early stage of progression. In the third stage treatment is combined, whereas in the fourth stage surgery is limited. Minimal resection that will provide oncological radicalism should be considered during planning of surgical treatment $[8,9]$. Small cell lung cancer is characterized by high dynamics of growth and the propensity for early spreading. It is sensitive to ionizing radiation and cytostatic drugs. Treatment of SCLC is to use combined therapy using chemotherapy and radiotherapy [10]. The survival time is associated with the 
progression of cancer. Five-year survival is $7-19 \%$ in stage III and $2 \%$ in the stage IV of cancer progression [11].

\section{Surgery, chemotherapy and radiotherapy in palliative care of lung cancer}

Palliative surgical procedures are carried out to relieve pain or restore organ function in order to ensure optimal patient QL up to death. Another purpose of this procedure is to improve the response to other treatments such as chemotherapy and radiotherapy, increasing their efficiency and prolonging survival free of cancer progression. Palliative treatment is one of the methods of treatment of patients with chronic, progressive, life-limiting illness with different times of survival. Historically, palliative surgery has not been offered for patients with advanced cancer. It was argued that this approach extends the hospital stay, increases medical costs, causes more frequent complications and higher mortality. The procedure requires oncologic surgeons who have experience and skills for decision-making in order to appropriately identify patients for whom palliative surgery can benefit. According to Hanna et al., the best clinical results of palliative surgery are achieved in patients whose expected survival is at least three months and performance status according to Karnofsky exceeds 50\% [12]. Palliative surgical treatment in patients with advanced cancer includes tumor bypass procedures, endoscopic procedures, partial resection of the tumor, and the removal of metastases. Surgical intervention may be beneficial in patients with lung cancer, if there is airway obstruction, hemoptysis, pleural or pericardial exudate, or metastases to the brain or bone. Symptoms such as severe breathlessness, wheezing, or hemoptysis need rapid implementation of bronchoscopy. Changes inside the airway lumen or airway pressure from the outside may be the causes of airway obstruction. Bronchoscopy could be very effective in these cases $[9,13]$.

Central airway obstruction develops in about $30 \%$ of patients with lung cancer [14]. Stents are inserted into the airways that are narrowed by the tumor ingrown to their lumen and by changes pressing from the outside. This method can be combined with, for example, expanding airways with a balloon or destruction of tumor by laser. Airway pressure by blood vessel from the outside is a contraindication for introduction of stents. This can result in major bleeding and lead to death [9]. Stenting of veins carries relatively minor complications. The worst of these is the migration of the stent. This can be avoided by ensuring adequate stent diameter, large enough to cover the entire stenosis. Infectious complications are rare and can be avoided by applying the principles of sterility $[15,16]$.

In a retrospective study involving 65 patients with lung cancer considerable relief after stenting was observed in $98 \%$ of patients [14]. Brutsche et al. studied 144 patients with advanced NSCLC who received palliative chemotherapy. They evaluated whether central airway obstruction was a negative prognostic factor. Median survival period was 8.4 months for patients without airway obstruction and 8.2 months in patients with central airway obstruction. Significant differences in this aspect were not observed. Central airway obstruction does not seem to be a bad prognostic factor but in order to improve the quality of life the introduction of the stent is justified [17].

Chemotherapy and/or radiotherapy are the foundation for treatment of advanced lung cancer. Cisplatin or carboplatin in combination with vinorelbine, gemcitabine, and etoposide are the most commonly used chemotherapeutic agents. Treatment is associated with toxicity regardless of the kind of cytostatic agent used. Side effects may occur immediately after administration, during hospitalization, or later. The most serious complication is reduced production of neutrophils. Neutropenia can lead to viral, bacterial and fungal infections which may cause death of the patient. It is important to examine the morphology of peripheral blood after chemotherapy. This allows adjuvant treatment to be introduced [18]. Palliative chemotherapy can relieve pain, cough and other ailments as well as prolonging survival time. If there is shortness of breath following the toxic effects of chemotherapy on pulmonary parenchyma discontinuation of administration of cytotoxic drugs and incorporation of steroids is necessary. When chemotherapy starts to increase side effects then it should be discontinued [9].

Radiotherapy is used as a radical, palliative or complementary treatment in more than $60 \%$ of patients. Technique and radiation doses depend on the extent of the tumor and general health condition. Endobronchial treatments such as brachytherapy are indicated in case of disturbance of ventilation in the course of airway narrowing. Palliative radiation therapy can alleviate symptoms in $41-95 \%$ of cases [10]. Palliative radiotherapy is effective in patients with pain and hemoptysis while in the case of dyspnea and cough to a lesser extent. Symptomatic metastases to the central nervous system or bone are other indications for its use. Intrabronchial brachytherapy may be used as a palliative treatment in case of existing symptoms of airway obstruction [19]. During the analysis of 1250 patients with NSCLC treated with palliative radiotherapy satisfactory results were achieved. As many as $92 \%$ of them tolerated this method of treatment. Relief of symptoms was observed in 54\% of patients for cough, $68 \%$ for hemoptysis, $51 \%$ for chest pain, $38 \%$ for dyspnea, $12 \%$ for hoarseness and $8 \%$ for dysphagia. Early treatment of toxicity has been implemented in $4.6 \%$ of patients and consisted of pneumonia in $2.3 \%$, intense nausea and vomiting in $0.6 \%$, and severe inflammation of the esophagus in $0.5 \%$ of patients [20].

\section{Palliative care in patients with lung cancer}

According to the World Health Organization (WHO), "Palliative care is a way of dealing that improves the quality of life of patients and their families facing the problems associated with life-threatening illness, through the prevention and alleviation of suffering, the early identification of problems and the best assessment and treatment of pain and other physical, psychosocial and spiritual problems" [21, 22]. In Poland, about 90 thousand people die due to neoplastic disease each year, $55.3 \%$ of them in hospital and $44.2 \%$ at home. The number of people needing palliative care will increase due to the aging population and expected increase in morbidity and mortality from cancer. Therefore, providing 
good quality care in accordance with the standards of the WHO becomes more and more important [23].

Almost $60 \%$ of patients with lung cancer are not eligible for radical treatment at the time of diagnosis. Soothing and supportive treatment is a treatment of choice [10]. Currently, palliative inpatient and home care are used in patients who present with symptoms of constant, severe dyspnea at rest, chronic coughing, severe pain, cachexia and fatigue, anxiety and depression as well as significantly reduced physical and intellectual activities. It is important that when the patient is aware of impending death, he or she can say goodbye to loved ones, complete all of the matters and meet their spiritual needs. It is important not to use aggressive medical treatment that prolongs the time of dying unnecessarily [24].

Knowledge about various methods of palliative procedures allows one to alleviate the symptoms of patients in an advanced stage of the disease with an expected short survival period. During conversation the doctor should assess symptoms and provide treatment options for the patient and her/his family. The deterioration of QL is associated with the awareness of having lung cancer. The decrease of QL is evoked by problems caused by the primary tumor, metastasis, paraneoplastic syndromes and treatment [25]. Palliative care should be planned by a multidisciplinary team, taking into account fitness status (WHO scale, Zubord and Karnofsky scale) and patient preferences.

In recent years, numerous studies have been conducted and their objective is to draw attention to the implementation of earlier initiation of care provided by the palliative care team and specialist nursing care in patients with cancer. Temel and colleagues evaluated the impact of the introduction of palliative care in patients with NSCLC at the time of diagnosis on changes in QL after twelve weeks of treatment. Participants were offered continuing the standard oncology care only or the introduction of palliative care with standard oncology care together. Quality of life in the group in which the palliative care was introduced was higher in comparison to the group of patients who underwent only standard cancer care. Patients in the group in which palliative care was introduced in older age required less aggressive treatment [26]. Although the use of hospice and other palliative care services is increased at the end of life, many patients are admitted to hospice in less time than the last three weeks before their death, which limits the benefits. Smith and colleagues argue that palliative care should be implemented together with the standard oncology care immediately after diagnosis in patients with NSCLC. Early implementation of palliative care improves the QL and alleviates coexisting symptoms. The introduction of palliative care causes appropriate referral of patients to the hospice and reduces the use of futile intensive care [27].

In accordance with the recommendations of the Council of Europe of 2003, each country should develop its own individual model of palliative care. It should take into account the health care system, social welfare, socio-economic conditions and cultural and religious considerations. The White Paper published by the European Association for Palliative Care (EAPC) provides guidance on norms and standards for hospice and palliative care in Europe [28-30]. In the integrated model that has been developed to improve palliative care for patients with advanced lung cancer, launching medical treatment should be preceded by QL assessment of patients and their families. A multidisciplinary team is appointed after receiving information about physical and mental fitness, social conditions as well as emotional state. Its members should include the patient's doctor, nurses, specialists in adjuvant treatment including social workers, psychologists, therapists, nutritionists and specialists in pain management. The team discusses the results of $\mathrm{QL}$ analysis then takes appropriate action in each area. Nurses implement their action including, for instance, education of the patient and his/her caregivers and they are supported by other team members and may refer patients to a palliative care center [9].

In the United States to inform the patient about a worse prognosis or about end-stage disease is a widely accepted practice. It is based on ethical principles of autonomy and informed consent. Hiding the truth by a physician can prevent the patient and members of his family from making emotional and financial preparations for an adverse outcome or death. Lack of information on the poor prognosis may also be associated with a loss of confidence in the doctor. Change of treatment plan from effort to cure to palliative care is a difficult decision. The decision is frequently taken when cure of cancer is not possible and surgical or conservative treatment is not effective due to the progression of the disease [12].

Most patients lose the ability to make decisions at the end of their life. During this period recommendations for actions must ensure respect for the wishes of the patient. They are included in the form of documents such as wills, power of attorney or oral instructions provided with family or friends. However, there often are difficulties arising from the ambiguous wording or disagreements between family members. The form of power of attorney in the final period of life allow one to avoid some of the limitations of a will written for life. Medical decisions included in the power of attorney should be taken into consideration.

If the doctor believes that the decisions contained in the power of attorney are not good for the patient, she or he should attempt to clarify the discrepancies, for example consult the bioethics committee [12].

\section{Symptom management and psychosocial support in advanced lung cancer}

\section{Dyspnea}

Dyspnea in cancer patients occurs at rest or during slight exertion, often accompanied by a feeling of anxiety. It may be acute or chronic in its character. The frequency of dyspnea increases as the disease progresses and occurs in 48$69 \%$ of patients at an advanced stage of the disease. In $70 \%$ of patients it occurs in the last 6 weeks of life. Taking into account all neoplastic diseases dyspnea occurs in lung cancer most often, worsening QL in the last stage of disease and it is a psychological burden to caregivers [15]. The causes of dyspnea in patients with advanced lung cancer are different. Recurrent pleural effusions is one of the most common. Despite making several punctures and using pharmacological treatment increasing fluid in the pleural cavity may indicate 
an advanced proliferative process. Clogging of the pleural lymphatic vessels by cancer cells, bronchial obstruction caused by cancer tissues and subsequent inflammation and atelectasis, infiltration of mediastinal lymphatic nodes and complications after radiotherapy or chemotherapy are the most common causes of accumulation of fluids in case of neoplastic disease. Videothoracoscopy (VATS) is used, among others, in diagnosis of pleural fluid. It allows one to examine the pleural cavity and take samples for histopathological examination. Once the diagnosis of malignant nature of pleural effusion is established, pleurodesis is recommended as palliative treatment. This treatment consists in the administration of a substance which causes permanent bonding of the wall and the visceral pleura together. The fluid has no space to accumulate, which brings relief to the patient. Remaining effusion accompanied by shortness of breath is an indication for performing pleurodesis. Pleurodesis should be preceded by drainage of the pleural cavity. It is recommended not to draw more than one liter of fluid and then $500 \mathrm{ml}$ every few hours. It is necessary to avoid a large amount of fluid during a single evacuation because of the risk of serious complications. Talc is used in a dose of $5 \mathrm{~g}$ in the form of a sterile powder or spray suspension. Complications are rare in the case of higher doses of talc, above $10 \mathrm{~g}$. Other agents used during pleurodesis are cytostatic drugs such as nitrogranulogen or bleomycin. They often cause side effects such as nausea and vomiting on the day of treatment, so use of antiemetics is a preventive action [31, 32].

Radiotherapy and chemotherapy can be iatrogenic causes of dyspnea. Irradiation of tumors located in the chest is also associated with covering the parts of a healthy lung. Postirradiation symptoms of pneumonia occur in approximately $10-15 \%$ of patients and include dyspnea, dry cough, fever and chest pain [32]. The set of quality of life questionnaires (EORTC QLQ-LC13, EORTC QLQ-C15-PAL, FACT-L) is used among others for assessment of dyspnea. In practice, the daily assessment of the severity of dyspnea is based on medical interview and determination of tolerance to physical efforts according to the New York Heart Association (NYHA). In addition to the scales it is important to gather information during interviewing and conduct appropriate clinical evaluation including shortness of breath and other symptoms from the respiratory system [25].

Drug therapy involves administration of bronchodilators, glucocorticosteroids and oxygen. Administration of benzodiazepines is considered as a second or third choice in situations where morphine and non-pharmacological methods are insufficient to control dyspnea. In the course of advanced lung cancer and other cancers it is recommended to use opioids for the symptomatic treatment of dyspnea. Morphine is the most commonly used drug while administration of codeine or dihydrocodeine may be considered in dyspnea with lower intensity. Its administration should be modified in the case of renal failure or another opioid with better renal profile must be used. Clotting disturbances (hypercoagulability) can be a cause of severe dyspnea - most commonly in patients with thrombosis of the superior vena cava. Pulmonary embolism can cause severe dyspnea. The drug of choice for the treatment of thrombosis is heparin administered as an intravenous drip infusion or infusion pump. Nursing procedures, calming the patient and ensuring a comfortable position may bring some relief in patients in the terminal phase of illness [24, 32].

Accumulation of fluid in the pericardial sac caused by infiltration or irritation of the pericardium can be another cause of severe breathlessness. The etiology of pericardial effusion is different; $35 \%$ of the cases have neoplastic origin. Even a small amount of pericardial fluid, depending on the speed of its collection, can cause cardiac tamponade. It is a threat to life and requires urgent decisions about treatment to be made. Beck's triad (low blood pressure, attenuation of heart sounds, jugular vein extension) is a characteristic set of symptoms occurring in tamponade. X-ray confirms the diagnosis of effusion in the pericardial sac, and thanks to echocardiography we can determine the amount of accumulated fluid. Puncture of the pericardium should be done under ultrasound guidance and fluid from the sac should be sent for biochemical, cytological and bacteriological examinations. In patients without hemodynamic problems and diagnosed with SCLC systemic therapy or radiotherapy is used. In the remaining group of patients making a pleuro-pericardial window (pericardiostomy) and application of obliterating cytostatics such as bleomycin and doxorubicin into the pericardial sac should be considered. Anthracyclines are among the most cardiotoxic anticancer drugs and often lead to cardiomyopathy. With a reduced amount of fluid treatment with NSAID or corticosteroids may be effective. Metastases to the lungs are 40 times more frequent than primary tumors and are the most common cause of malignant exudate in the pericardial sac [15, 33, 34].

Oxygen therapy is used for relief of dyspnea. Decrease in oxygen saturation below $90 \%$, as measured by a pulse oximeter, is a confirmation of hypoxemia. Central cyanosis is a symptom of hypoxia. Oxygen therapy is used most often at home in small doses of oxygen, $1-3 \mathrm{l} / \mathrm{min}$. It is recommended to use a nasal catheter and nasal mucosal lubricating cream to prevent irritation of the mucous membrane around the catheter. The use of an oxygen mask is not recommended as it causes dryness of mucous membranes of the mouth and difficulties in fluid intake and communication with loved ones [25].

\section{Pain}

Pain occurs in $25-50 \%$ of patients with lung cancer as a result of tumor infiltration in the parietal pleura, chest wall or when there is pulmonary embolism or pneumonia [10]. Pain that occurs in patients with advanced cancer is usually chronic and permanent. Sharp, piercing pain occurs periodically and it is associated with painful procedures such as therapeutic and diagnostic requiring a separate procedure. Neuropathic pain arises as a result of nerve injury in the pain pathway. As a general rule it is more difficult to treat and is identified in 30-40\% of patients [33]. Pancoast tumor is a form of bronchial cancer located in the area of the apex of the lungs. Pain that occurs in the area of the shoulder is one of the first symptoms. The pain is caused by infiltration of the brachial plexus, parietal pleura and first and third ribs. Additionally, Horner's syndrome may occur, caused by infiltration 
or compression of the sympathetic ganglia. Before 1950 Pancoast tumor was considered inoperable [35]. Anticonvulsants such as phenytoin, carbamazepine and clonazepam are also used for control of neuropathic pain. Tricyclic antidepressants are also helpful in treating that pain. They increase the effects of opioids and have analgesic properties [36].

Pain affects all dimensions of QL and affects the ability of patient to survive treatment, recover or achieve a peaceful death [37]. Analgesic therapy includes non-narcotic analgesics, opioids and complementary medicines if necessary. Opioids are critical to provide effective analgesia in cancer pain. Morphine is the most commonly used opioid for moderate to severe pain. It can be used transdermally or rectally in patients who cannot take it orally. It is necessary to prevent constipation and to monitor the frequency of defecation during opioid treatment. Side effects can be reduced by switching to another opioid [25, 36]. The patient and his family can avoid the use of opioids because of fear of addiction. Over the past 30 years, cancer pain management has become a priority in oncology [37]. There are few data on the evaluation of the use of analgesics in patients with lung cancer. In studies of pain relief in palliative care of patients with lung cancer, $92 \%$ of them reported pain, of whom $52 \%$ attributed it directly to their illness, and 38\% said that pain was associated with cancer treatment. The use of analgesics was higher in patients receiving radio- and chemotherapy compared to patients treated surgically. Among patients who reported pain, 33\% had used no painkillers. This was associated with a fear of addiction or lack of financial resources to buy drugs [38]. Nowicki and colleagues evaluated the cancer pain in palliative care in patients with lung cancer. The study included 50 patients who were under home care and inpatient hospice care. A visual-analog scale (VAS) was used to assess pain. Before palliative care pain that was felt by patients provided with home care was assessed at 6.2 points on the VAS scale and 5.4 points in patients under inpatient care. Strong opioids were the most commonly used analgesics. Half of patients experienced side effects, most commonly constipation. After treatment the pain intensity decreased to 2.6 points in patients under home care and 1.6 points for patients treated in an inpatient center of palliative care. In $86 \%$ of patients the dose taken was sufficient [39].

\section{Cough}

In $47-86 \%$ of patients cough is one of the symptoms of lung cancer. Coughing is usually associated with excessive production of mucus, inflammatory secretions or presence of blood in the airways. Current practice in the treatment of cough in patients with lung cancer is empirical in character, primarily focused on opioids administered orally. Current guidelines on the treatment of cough are broad and unspecific, and focus on the treatment of cough in non-neoplastic respiratory diseases. Societies which have provided guidelines include the American College of Chest Physicians (ACCP), European Respiratory Society (ERS) and the British Thoracic Society (BTS). An assessment of adequacy, usefulness and clarity of the guidelines was carried out by an international group of experts, among whom there were nine palliative care consultants, four oncologists and two nurses specializing in palliative care. A pyramid for the treatment of cough in patients with lung cancer was developed. A detailed medical history is essential to determine the cause of cough. The assessment should include the type of cough, trigger factors and its impact on QL. Many patients with lung cancer have coexisting diseases that may cause coughing. In addition to treatment that is directed at the cause of cough, pharmacotherapy consists in the administration of antitussive drugs and opioids. Oral corticosteroids that are taken for 14 days may alleviate coughing caused by direct infiltration of the bronchus by the tumor. Along with the cough, gastro-intestinal reflux may occur; thus administration of metoclopramide or domperidone may be necessary in selected patients $[15,40]$. Codeine is the most commonly administered antitussive opioid, often in complex preparations with paracetamol. Constipation is a complication of systematic administration and therefore prophylactic administration of laxatives is necessary. Dihydrocodeine also has an antitussive effect. Tramadol is characterized by less potent antitussive medicine. In the case of severe cough with pain in the chest, morphine or other strong opioids such as methadone are recommended. Co-administration of more than one opioid is not justified $[36,40]$.

In patients with lung cancer expectorant drugs are rarely used. The reason is their unpleasant taste, common side effects and low therapeutic efficacy. Mucolytic agents that can be given by inhalation or orally also have limited use. Acetylcysteine and bromhexine are most commonly used. Administration of mucolytic drugs in lying, weak patients not having the strength for expectorating sputum seems unreasonable. In this case, the administration of drugs that inhibit secretion in the bronchial tree, such as hyoscine derivatives, should be considered. The use of inhaled anticholinergic drugs reduces the movement of cilia and mucus congestion in the bronchi, which may contribute to the severity of cough [15].

\section{Hemoptysis}

Hemoptysis is the presence of blood in the bronchial secretions. It is a symptom that occurs in about $20 \%$ of patients with lung cancer. Pulmonary hemorrhage, which often leads to death, is observed in $3 \%$ of patients. The causes of hemoptysis include pulmonary embolism, anticoagulation therapy, trauma after bronchoscopy, fistulas, bronchiectasis, and others. Coughing more than $150 \mathrm{ml}$ of blood during 24 hours is defined as massive hemoptysis. It is most often associated with damage to arterial vessels. In this case bronchoscopy is carried out for location and local treatment. Pressure, tamponade, adrenaline injections, cold saline solution, hemostatic agents, and removal of blood clots are the treatments used to stop bleeding. In some cases of failure of the above-mentioned procedures bronchial artery embolization is considered. In adjunctive therapy and at the terminal stage of disease drugs that inhibit fibrinolysis such as tranexamic acid, and medications that support hemostasis such as vitamin $\mathrm{K}$ and antitussives are used. In the terminal phase of disease mitigation procedures are applied such as an appropriate position to prevent choking, 
anti-anxiety drugs (diazepam, midazolam) and bed linen in dark colors. The presence of loved ones, nurses, and a physician is important. Palliative radiotherapy brings good results in the case of persistent hemoptysis. External radiation (teletherapy) is used most frequently while in the case of intrabronchial lesions endobronchial brachytherapy HDR is recommended $[15,24]$.

\section{Superior vena cava syndrome}

As a result of neoplastic changes localized in the mediastinum which may compress the superior vena cava, a set of symptoms called superior vena cava syndrome (SVCS) may occur. This leads to difficulty of venous blood outflow from the head and upper limbs. It is a common complication of malignant neoplasms, especially lung cancer and lymphomas. It is estimated that $2-4 \%$ of patients with lung cancer develop SVCS. About 75\% of cases are caused by lung cancer. The most common symptoms include congestion and swelling of the face, upper chest and shoulders, hoarseness, shortness of breath, fainting on standing at the slope, headache, dizziness and extension veins in the neck and the chest wall $[15,16]$.

Superior vena cava syndrome most often takes a chronic course; obstruction of the superior vena cava grows slowly, producing a collateral circulation. Sudden narrowing within the superior vena cava may occur as a result of acute thrombosis. Symptoms of cerebral and larynx edema occur in this case. It is a life-threatening state for the patient and requires making early treatment decisions. The choice of treatment depends on the dynamics of the disease and the histopathological diagnosis. Surgical treatment should be considered in some cases. In NSCLC radiotherapy is a treatment of choice, whereas it is chemotherapy in the case of SCLC. Corticosteroids are used as palliative treatment. Dexamethasone is administered most frequently. The use of heparin in SVCS because of risk of thrombosis in the superior vena cava is reasonable. The prognosis for SVCS depends on the cause of venous obstruction. In this case, all treatments are palliative and improving the quality of life is their $\operatorname{aim}[16,40]$.

\section{Cancer fatigue syndrome}

Cancer fatigue syndrome is a persistent feeling of tiredness and exhaustion, or anti-cancer treatment, whose intensity is not proportional to the current activity and which affects everyday life functioning. It is associated with primary disease and its treatment, the subjective physical, mental, emotional and cognitive feelings, exhaustion or fatigue that interfere with proper functioning. Difficulties in performing activity, reduced ability to maintain it (fatigue) and mental fatigue (difficulties in concentration, memory problems) are observed in such patients. This symptom is observed periodically in $70 \%$ of patients with lung cancer, while in 30\% of them it is observed constantly. Treatment of fatigue syndrome should be based on the treatment of potentially reversible causes such as water-electrolyte disorders or depression, and on symptomatic treatment. It includes pneumonological rehabilitation with psychological support, medication and physical activity. Cancer fatigue syndrome impairs functioning in everyday life, but it is not always recognized by physicians and therefore is not treated adequately $[24,41,42]$.

\section{Psychological problems}

Lung cancer causes psychological consequences. Hill and colleagues studied the concerns of patients with lung cancer after diagnosis, and asked whether these effects were discussed by the teams involved in patient care. The most common concerns were the disease in itself, and concerns about family and about the future associated with the disease. Interviews were conducted in the hospital, at home and in the outpatient clinic. The authors found that only $43 \%$ of patients discussed troubling issues with their doctors. Symptoms of the disease were less alarming than psychosocial symptoms [43]. Studies on well-being of people with lung cancer found that those who better understand the meaning of life feel better mentally and less suffering. Aspects of spirituality, the sense of life and prayer have a positive impact on mental and physical functioning in this group of patients [44]. Sarna et al. assessed the quality of life and the sense of the disease in women with lung cancer. 19\% of patients had advanced disease. Depressed mood, younger age, and a negative approach to the nature of the disease were associated with deterioration of quality of life. Depression was experienced by $35 \%$ of women while distress due to diagnosis and affected family was experienced by more than 75\% [45]. Gilbert and colleagues noted that in patients with advanced cancer there also occurred anxiety, depression, social isolation and fear apart from symptoms from the respiratory system. Such effects lower the QL in these patients. Many patients suffer from the experience of fear, anxiety and panic. Lack of sleep and poor sleeping quality also affect the lower QL [46].

Supportive care is part of the oncological treatment. One of the main purposes of this measure is to fight against and prevent adverse consequences of treatment such as nausea, vomiting, diarrhea, weakness, infection, leukopenia and anemia. An important element of this procedure is to conduct parenteral nutrition. Supportive care includes nursing, medical, psychological, social and spiritual care as well as rehabilitation. The nurse is a trustee of the patient and her/his family in going through the emotion, spiritual pain and social problems, and is a person who helps in getting in contact with other members of the multidisciplinary team $[9,13]$.

In conclusion, palliative treatment is an important component of oncological treatment. It should also be a standard for other life-limiting illnesses. Early implementation of palliative care improves the quality of life and alleviates co-existing symptoms, and makes the patient's referral to a hospice more appropriate as well as reducing the futile use of an intensive care unit. The introduction of palliative care can relieve or alleviate the disease and protect against complications. All activities give benefits for the patient, improve quality of life, provide pain relief, and improve functioning in the family. Chemotherapy and/or radiotherapy are relevant to the proceedings in advanced lung cancer. Palliative chemotherapy can relieve pain and 
other ailments as well as prolonging the survival period. Radiotherapy is used as a radical, palliative or complementary treatment [9].

Home palliative care exercised by the interdisciplinary team can enable the patient to stay at home, in an environment familiar to her/him, where she/he uses the independence and comfort not available in the hospital environment.

Appropriate equipment is delivered to home which allows care and rehabilitation and also equipment necessary to conduct therapy, e.g. an infusion pump.

Visits of qualified medical personnel allow good communication with patients and their families, reduction or elimination of the risk of bedsores, monitoring of therapy, and informing about proceedings in the event of sudden health hazards. Staying in inpatient care units is for patients who cannot be treated at home because alleviation of symptoms is not satisfactory [13].

The authors declare no conflict of interest.

\section{References}

1. Yancik R, Ganz PA, Varricchio CG, Conley B. Perspectives and comorbidity and cancer in older patients: approaches to expand the knowledge base. J Clin Oncol 2001; 19: 1147-51.

2. Lutostańska I, Mrówczyńska E, Mazurkiewicz B, Stachowiak A. Analiza Zintegrowanego Systemu Opieki nad osobami umierającymi na oddziale opieki paliatywnej - wszechstronna ocena potrzeb pacjentów o okresie terminalnym choroby nowotworowej. Med Paliat 2010; 2: 100-6.

3. Thun MJ, DeLancey JO, Center MM. The global burden of cancer: priorites for prevention. Carcinogenesis 2010; 3: 100-10.

4. Foster JA, Salinas GD, Mansell D. How does older age influence oncologist`s cancer management? The Oncologist 2010; 15: 584-92.

5. Hocking WG, Hu P, Oken MM. Lung cancer screening in the ran domized Prostate, Lung, Colorectal, and Ovarian (PLCO) Cancer Screening Trial. J Natl Cancer Inst 2010; 102: 722-31.

6. Ramalingam SS, Owonikoko TK, Khuri FR. Lung Cancer: New biological insights and recent therapeutic advances. Cancer J Clin 2011; 61: 91-112.

7. Leppert W. Jakość życia chorych na zaawansowanego raka płuca objetych opieką paliatywną stacjonarną i domową. Medycyna Paliatywna 2010; 1: 25-34

8. Kowalewski J, Dancewicz M. Rak płuca: leczenie operacyjne chorych z ograniczoną rezerwą oddechową. Kardiochir Torakochir Pol 2008; 5: 413-7.

9. Ferrell B, Koczywas M, Grannis F, Harrington A. Opieka paliatywna w raku płuca. Chirurgia po Dyplomie 2011; 6: 14-25.

10. Rzymian W. Rak płuca. Forum Medycyny Rodzinnej 2008; 2: 407-19.

11. Laprus I, Adamek M, Kozielski J. The need of lung cancer screening - new evidence, new expectations. Pneumonol Alergol Pol 2011; 79: 419-27.

12. Hanna NN, Bellavance E, Keay T. Operacje paliatywne w onkologii. Chirurgia po Dyplomie 2012; 3: 5-12.

13. Łuczak J, Kotlińska-Lemieszek A. Opieka paliatywna/hospicyjna/medycyna paliatywna. Nowiny Lek 2011; 80: 3-15.

14. Saji H, Furukawa K, Tsutsui H, Tsuboi M, Ichinose S, Usuda J, Ohira T, Ikeda N. Outcomes of airway stenting for advanced lung cancer with central airway obstruction. Interact Cardiovasc Thorac Surg 2010; 11: 425-8.

15. Leppert W. Leczenie objawów ze strony układu oddechowego u chorych na nowotwory. Nowiny Lek 2011; 80: 32-46

16. Warren P, Burke C. Endovascular management of chronic uppe extremity deep vein thrombosis and superior vena cava syndrome. Sermin Intervent Radiol 2011; 28: 32-8.
17. Chajed PN, Baty F, Pless M, et al. Outcome of treated advance nonsmall cell lung cancer with and without airway obstruction. Chest 2006; 130: 1803-7.

18. Brajer B, Batura-Gabryel H. Opieka pozaszpitalna nad chorym w trakcie chemioterapii raka płuca. Przew Lek 2007; 1: 142-5.

19. Krzakowski M, Dziadziuszko R, Jassem J, Olszewski W, Orłowski T, Reinfuss M, Roszkowski-Śliż K, Rzyman W. Nowotwory złośliwe płuca i opłucnej. Zalecenia postepowania diagnostyczno-terapeutycznego w nowotworach złośliwych: 2009. Via Medica 2009; Gdańsk 69-84.

20. Reinfuss M, Mucha-Małecka A, Walasek T, Blecharz P, Jakubowicz J, Skotnicki P, Kowalska T. Lung Cancer 2011; 71: 344-9.

21. Ciałkowska-Rysz A. Sytuacje i wyzwania opieki paliatywnej w Polsce. Med Paliat 2009; 1: 22-6.

22. Palliative Care: The World Health Organizations Global Perspective. J Pain Symptom Management 2002; 24: 91-6.

23. Kaczmarek MS, Żółtak-Bączkowska K, Szymkowicz-Kowalska M Karakiewicz B. Analiza problemów medycznych i psychospołecznych pacjentów objętych opieką Hospicjum Domowego w Szczecinie w 2007 r. Med Paliat 2011; 2: 81-6.

24. Jassem E, Batura-Gabryel H, Cofta S, et al. Reccomendation of Polish Respiratory Society for palliative care in chronic lung diseases. Pnemonol Alergol Pol 2012; 80: 41-64.

25. Kvale PA, Selecky P, Prakash UB. Palliative care in lung cancer. ACCP evidence-based clinical practice giudelines. 2nd edition. Chest 2007; 132 (Suppl 3): 368S-403S.

26. Temel JS, Greer JA, Muzikansky A, et al. Early palliative care for patients with metastatic non-small cell lung cancer. N Engl J Med 2010; 363 : 733-42.

27. Smith TJ, Temin S, Alesi ER, et al. American Society of Clinical Oncology provisional clinical opinion: the integration of palliative care into standard oncology care. J Clin Oncol 2012; 30: 880-7.

28. Ciałkowska-Rysz A, Dzierżanowski T. Ocena sytuacji w opiece paliatywnej w Polsce w 2011 roku. Med Paliat 2011; 4: 214-20.

29. Radbruch L. White Paper on standards and norms for hospice and palliative care in Europe. Eur J Pall Care 2009; 16: 278-89.

30. Radbruch L. White Paper on standards and norms for hospice and palliative care in Europe. Eur J Pall Care 2010; 17: 22-33.

31. Kądziołka W, Zamorski P, Lis A, Kobak G. Diagnostyka wideotorakoskopowa (VATS) nowotworowych wysięków w opłucnej. Wspolczesna Onkol 2002; 1: 20-23.

32. Jassem E, Jassem J. Duszność w przebiegu raka płuca. Pol Med Pal 2002; 1: 3-10.

33. Goleniewska B, Zielińska M. Tamponada serca jako pierwszy objaw kliniczny raka płuca. Onkol Prakt Klin 2011; 7: 37-39.

34. Meder J. Podstawy onkologii klinicznej: stany nagłego zagrożenia życia w onkologii. Warszawa 2011; 211-222.

35. Pitz CC, de la Rivière AB, van Swieten HA, Duurkens VA, Lammers JW, van den Bosch JM. Surgical treatment of Pancoast tumours. Eur J Cardiothorac Surg 2004; 26:202-208.

36. Ferrel B, Levy MH, Paice J. Managing pain from advanced cancer in the palliative care setting. Clin J Oncol Nurs 2008; 12: 575-581.

37. Paice JA, Ferrell B. The management of cancer pain. Cancer J Clin 2011; 61: 157-182.

38. Simone CB, Vapiwala N, Hampshire MK, Metz JM. Palliative care in the management of lung cancer: analgesic utilization and barriers to optimal pain management. J Opioid Manag 2012; 8: 9-16.

39. Nowicki A, Staszewska A. Ocena bólu nowotworowego w opiece paliatywnej u chorych na raka płuca. Pol Med Paliatywna 2006; 5 154-61.

40. Molassiotis A, Smith JA, Bennett MI, Blackhall F, Taylor D, Zavery B, Harle A, Booton R, Rankin EM, Lloyd-Williams M, Morice AH. Clinical expert guidelines for the management of cough in lung cancer: report of a UK task group on cough. Cough 2010; 6:9.

41. Kozak J, Turwoń A. Zespół żyły głównej górnej. Onkol Pol 1998; 3-4: 153-7.

42. Rzepka K, Nowicki A. Zespół zmęczenia u chorych na raka piersi. Współczesna Onkol 2010; 14: 321-325

43. Hill KM, Amir Z, Muers MF, Connolly CK, Round CE. Do newly giag nosed lung cancer patients fell their concerns are being met? Eur J Cancer Care (Engl) 2003; 12: 35-45.

44. Meraviglia MG. The effects of spirituality on well-being of people with lung cancer. Oncol Nurs Forum 2004; 31: 89-94. 
45. Sarna L, Brown JK, Cooley ME, Williams RD, Chernecky C, Padilla G, Danao LL. Quality of life and meaning of illness of women with lung cancer. Oncol Nurs Forum 2005; 32: E9-19.

46. Gilbert CR, Smith CM. Advanced lung disease: quality of life and role of palliative care. Mt Sinai J Med 2009; 76: 63-70

\section{Address for correspondence}

Andrzej Nowicki, Ass. Prof.

Department of Oncological Nursing

Ludwik Rydygier Collegium Medicum in Bydgoszcz

Nicolaus Copernicus University in Torun

ul. Technikow 3

85-801 Bydgoszcz

mobile: 602383210

e-mail: anow1_xl@wp.pl

Submitted: $\quad 13.08 .2012$

Accepted: $\quad 26.11 .2012$ 